\title{
HYDROXYAPATITE CLAY USED TO FILL THE GAP BETWEEN IMPLANT AND BONE
}

\author{
MASAAKI MARUYAMA
}

From Shinshu University, Matsumoto, Japan

A clay containing hydroxyapatite (HA) was developed for use as a filling material between an uncemented implant and bone. It consists of $55 \%$ HA granules greater than $0.1 \mathrm{~mm}$ in size with a homogeneous pore distribution and a porosity of $35 \%$ to $48 \%$ in a saline solution of sodium alginate $(6 \%)$.

Ti-6Al-4V alloy rods with smooth surfaces were implanted into the distal medullary canal of one osteotomised tibia of 32 Japanese white rabbits. Sixteen rods were inserted with HA clay and 16 without the clay to act as a control group. Six of each group were killed at one week and ten at 12 weeks postoperatively.

The pull-out strength of the implants with HA clay was significantly greater at 12 weeks $(p<0.05)$, as was the percentage of the area of the new bone $(p<0.05)$.

The study suggests that $H A$ clay has an osteoconductive property, allowing adequate bone fixation across a gap at an early stage. The use of HA clay to enhance the early stability of uncemented components may help to improve the functional outcome of total joint arthroplasty.

J Bone Joint Surg [Br] 1995;77-B:213-8.

Received 22 July 1994; Accepted after revision 10 October 1994

It is very difficult to achieve total contact between an uncemented prosthesis and host bone in total hip arthroplasty. There is always a gap unless special custom-fitted prostheses are used, and the problem is worse at revision arthroplasties.

In normal practice, the initial fixation of the prosthesis is provided by a few point contact areas, excessive stress on which may lead to loosening. Since the long-term success of the prosthesis depends on bone ingrowth (Carlsson et al 1988; Søballe et al 1991), it is essential that any gaps should be filled with newly-developed bone as soon as possible. Recent studies of uncemented porous-coated

M. Maruyama, MD, Instructor of Orthopaedic Surgery

Shinshu University School of Medicine, 3-1-1 Asahi, Matsumoto 390, Japan.

(1)1995 British Editorial Society of Bone and Joint Surgery

0301-620X/95/2983\$2.00 implants retrieved from patients have shown that skeletal fixation is primarily by fibrous tissue ingrowth, with no extensive bone ingrowth (Cameron 1986; Bobyn, Engh and Glassman 1987; Collier et al 1988; Cook et al 1988; Cook, Thomas and Haddad 1988; Engh, Bobyn and Petersen 1988).

Polymethylmethacrylate (PMMA) bone cement is used as a grout to provide mechanical fixation, and recent reports have confirmed relatively good long-term results (Schulte et al 1993; Wroblewski and Siney 1993; Neumann, Freund and Sørenson 1994). PMMA cement, however, has some adverse effects including poor affinity for host tissue and thermal injury which may lead to loosening (Goldring et al 1983; Mjöberg et al 1984). These problems of cement have never been solved.

Hydroxyapatite (HA) has been used to fill bone defects because of its non-toxic nature, its biocompatibility and osteoconductive properties (Jarcho 1981; Uchida et al 1990; Kamegaya et al 1994). The use of an HA coating for metallic prostheses has been shown to enhance host bone apposition and initial implant fixation provided there is a static fit (Thomas et al 1987; Geesink, de Groot and Klein 1988; Tisdel et al 1994) and minimal movement at the interface (Søballe et al 1993). There was, however, poor development of new bone into gaps between the implant and the endosteum except where the implant was in reasonably close contact (Bauer et al 1991; Furlong and Osborn 1991; Geist, Stracher and Grove 1991). Some unsatisfactory results have been reported: Shen et al (1992) found that 15 of $18 \mathrm{Ti}-6 \mathrm{Al}-4 \mathrm{~V}$ femoral intramedullary rods showed breakdown at the interface between the plasmasprayed HA coating and the titanium core, and Collier et al (1993) reported evidence of considerable loss of the HA coating on retrieved hip components.

It seems sensible that gaps between the prosthesis and bone should be filled with some type of HA at the time of surgery, to promote osteoconduction. Complete filling with HA granules would be difficult for an irregular or very narrow gap, and densely-packed granules would often interfere with the insertion of the prosthesis. I have therefore developed a clay which is easy to handle and use to fill any irregular gap (Maruyama et al 1995). It is produced by the mixture of granulated $\mathrm{HA}$ and a viscous solution of sodium alginate (Fig. 1). I have investigated its biological behaviour and influence on bone growth in load-bearing conditions. 


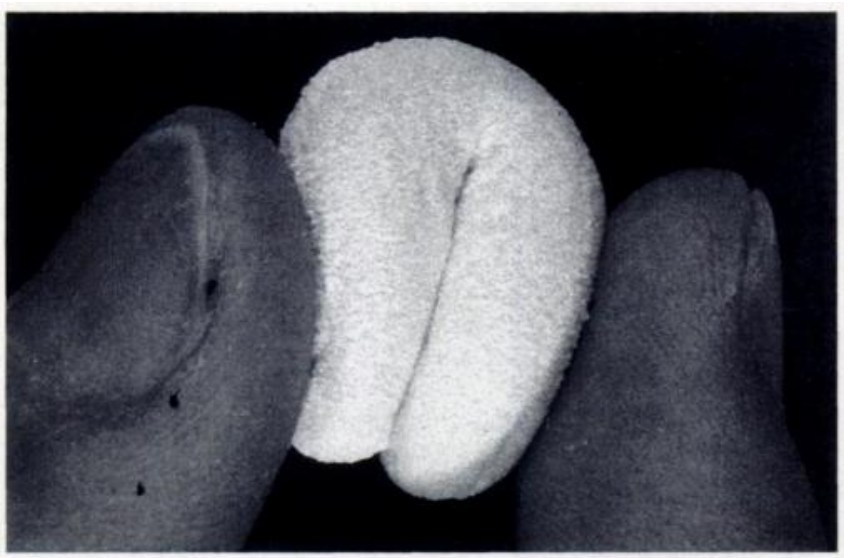

Fig. 1

Hydroxyapatite (HA) clay is a mixture of HA granules and a saline solution of sodium alginate. The clay looks and handles like the doughy state of polymethylmethacrylate bone cement.

\section{MATERIALS AND METHODS}

HA clay. The HA clay was made by the mixture of granulated $\mathrm{HA}\left(\mathrm{Ca}_{10}\left(\mathrm{PO}_{4}\right)_{6}(\mathrm{OH})_{2}\right)$ (Sumitomo Cement Co Ltd, Kanda, Tokyo, Japan), sodium alginate $\left(\mathrm{C}_{6} \mathrm{H}_{7} \mathrm{O}_{6} \mathrm{Na}\right)_{n}$ (Kyosei Pharmaceutical Co Ltd, Otaru, Hokkaido, Japan) and saline solution, aiming at $55 \% \mathrm{HA}$ and $6 \%$ sodium alginate. The HA granules were made by pulverising HA blocks, calcined at $1150^{\circ} \mathrm{C}$. They had a homogeneous pore distribution with a pore size of 0.05 to $0.3 \mathrm{~mm}$ and a porosity of $35 \%$ to $48 \%$. The range of size of granules in the clay was 0.1 to $0.3 \mathrm{~mm}$. Sodium alginate powder was dissolved in water to form a viscous solution.

Implants. Intramedullary implants with a smooth surface were made from Ti-6Al-4V alloy. Each implant had an interlocking mechanism to allow it to be used for internal fixation and later for mechanical testing, with a conical load-bearing portion and a cylindrical portion (Fig. 2).

Animals and operative technique. Thirty-two adult, male, skeletally mature Japanese white rabbits weighing between

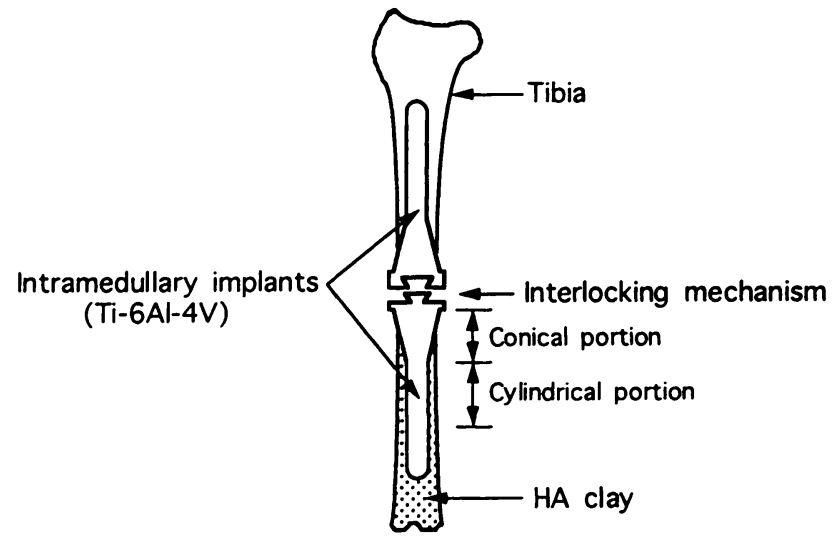

Fig. 2

Diagram of the experiment. The intramedullary implants $(3 \mathrm{~mm}$ outer diameter, $40 \mathrm{~mm}$ long) are of Ti-6Al-4V alloy. One implant was placed in the reamed distal tibia with or without HA clay; its pair was placed in the proximal tibia, and the proximal and the distal parts were interlocked.
3.5 and $4.5 \mathrm{~kg}$ were used. They were anaesthetised by the intravenous injection of sodium 5-ethyl-5-barbiturate $(25 \mathrm{mg} / \mathrm{kg})$. Using a sterile technique, unilateral mid-tibial osteotomies were performed and the distal medullary canal was reamed gently with a rasp. In 16 rabbits, an implant with HA clay was inserted into the distal medullary canal, and its paired implant placed in the proximal medullary canal. The implants were then interlocked (Fig. 2). In the other 16 rabbits the distal implants were fitted with no HA clay. All the implants, with or without HA clay, were advanced in the medullary canal to obtain a firm press-fit.

Gentamicin $(20 \mathrm{mg})$ was given intramuscularly immediately after the operation, and all implanted limbs were held in a below-knee cast for one week to prevent excessive movement. The animals were then allowed to move freely in their cages. Six HA tibiae and six control tibiae were harvested at one week and ten of each group at 12 weeks. The proximal tibiae were discarded since there had not been a uniform fit.

Radiological evaluation. Each distal tibia was cleared of soft tissue and radiographed. Loosening was defined by the presence of continuous radiolucency at the bone-implant interface or of progressive subsidence.

Mechanical testing. The strength of the implant-bone interface was evaluated by a pull-out test. Each distal tibia was embedded in PMMA cement with its proximal part exposed and attached to a universal testing machine (Imada Co Ltd, Toyohashi, Aichi, Japan) using an X-Y slide-jig. This jig allowed the sample to become aligned during the test and ensured that only a tensile load was applied. A paired proximal implant was locked on and attached to a load-cell. The implant was then pulled out from the tibia at a rate of $3 \mathrm{~mm} / \mathrm{min}$, and load-displacement curves were recorded. All the mechanical tests were performed within 24 hours of harvesting the sample. The pull-out force divided by the exterior surface area of the implant gave the interface shear strength.

Histological evaluation. After the mechanical test, each tibia was fixed in $10 \%$ formalin and embedded in methylmethacrylate. Undecalcified and polished histological specimens of cross-sections of the cylindrical portion of each implant were surface stained with toluidine blue for light microscopy. The sections were examined histologically and by contact microradiography.

An image analyser (LUZEX-3; Nireco Co Ltd, Hachioji, Tokyo, Japan) was used to measure histological areas, recording the cross-sectional area of new bone and of HA granules. Percentages were calculated for each of the whole area of the gap between the implant and cortical bone.

The results were analysed by unpaired $t$-tests, considering $p$ values of less than 0.05 to be significant.

\section{RESULTS}

All the implants allowed good function under load-bearing conditions until the rabbit was killed. Macroscopic observa- 
tion showed no migration of HA granules into the soft tissue around the tibiae.

Radiological evaluation. Radiographs of the specimens at 12 weeks postoperatively showed no evidence of loosening

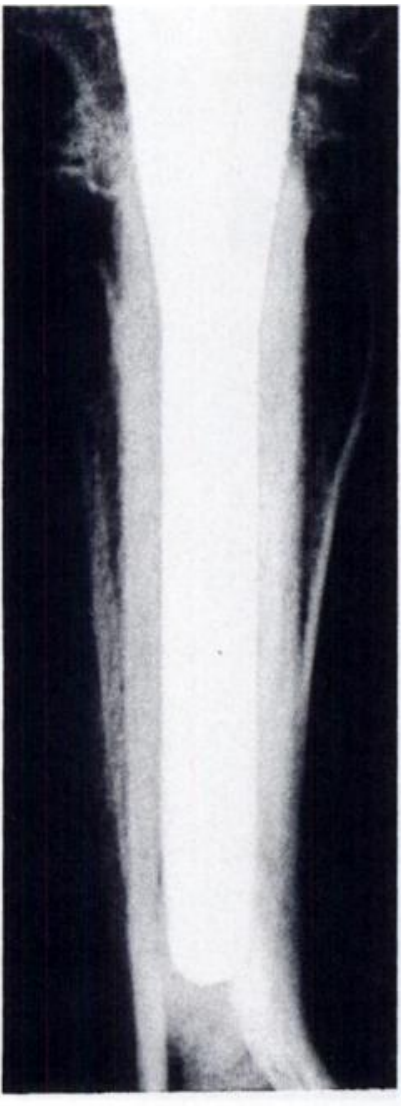

Fig. 3a

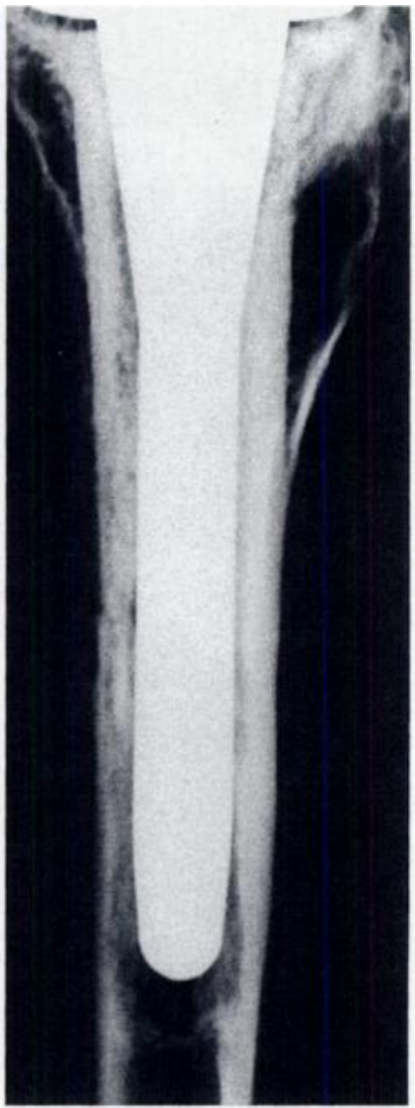

Fig. 3b
Radiographs at 12 weeks postoperatively. Figure 3a - Distal tibia with HA clay showing no radiolucency or subsidence. Figure $3 b-$ Distal tibia without HA clay showing continuous radiolucency, subsidence of the implant, and endosteal bone bridged by a pedestal.

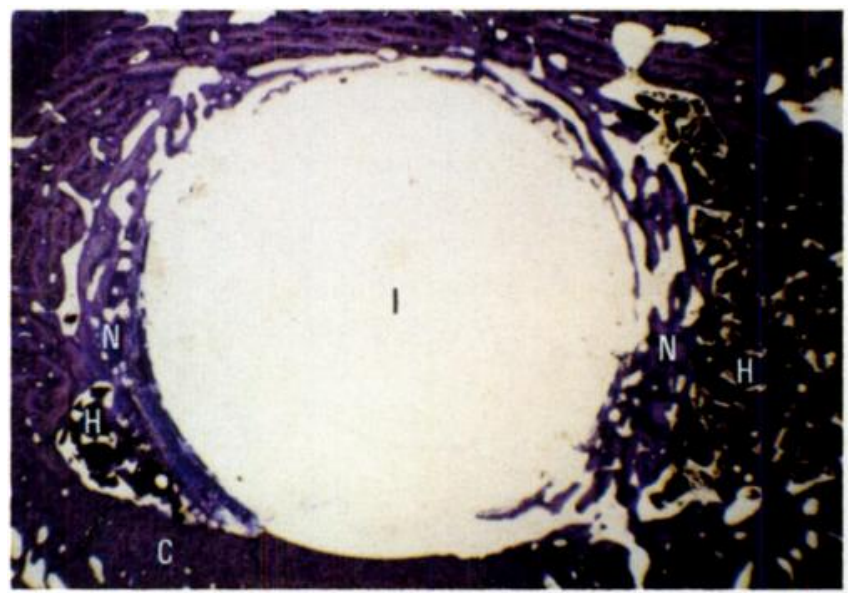

Fig. 5a in the HA group, with definite loosening in all of the control group (Fig. 3).

Mechanical testing. The pull-out strength of the implants with HA clay was significantly greater than that of those without HA clay at 12 weeks $(\mathrm{p}<0.05 ; 0.45 \pm 0.06 \mathrm{MPa}$ for the implants with HA clay compared with $0.04 \pm$ $0.04 \mathrm{MPa}$ for the control group). There was, however, no significant difference between the groups of implants at one week $(0.03 \pm 0.03 \mathrm{MPa} \vee 0.03 \pm 0.02 \mathrm{MPa})$. All the implants without HA clay and those with HA clay at one week were easily extracted (Fig. 4).

Histological evaluation. The histological sections with HA clay at 12 weeks showed that the gap between the implant and cortical bone had been filled with newly-developed mature bone and HA granules. The new bone was in direct

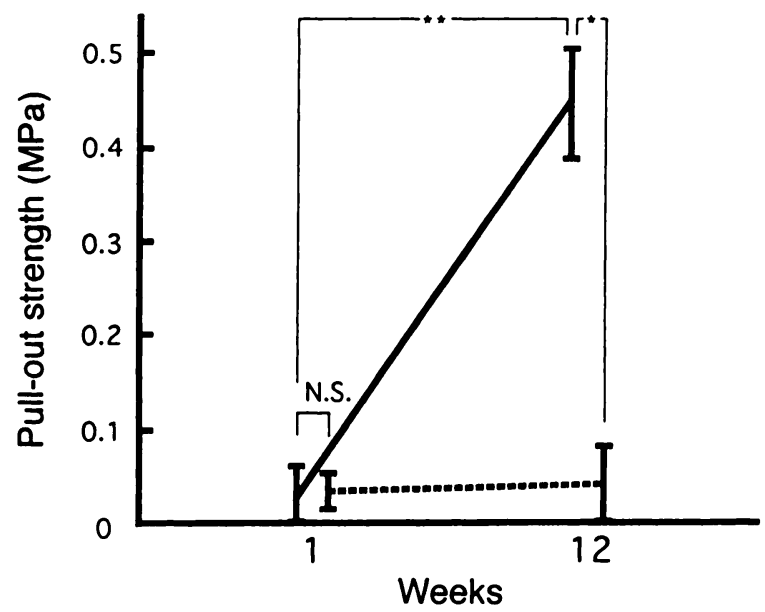

Fig. 4

Pull-out strengths of the implants. Those with HA clay (solid line) were significantly better fixed than those without HA clay (dotted line) at 12 weeks $(*, p<0.05)$ and those with HA clay at one week $\left({ }^{* *}, p<0.005\right)$. There was no significant difference between the implants at one week. The error bars indicate the standard deviation of the mean.

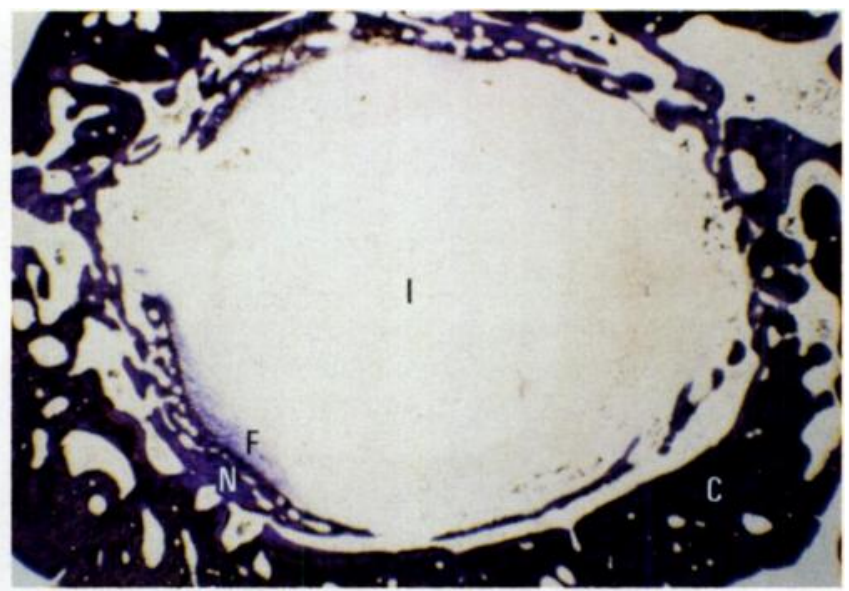

Fig. 5b

Photomicrographs at 12 weeks (toluidine blue $\times 10$ ). Figure $5 \mathrm{a}-$ With HA clay, showing the gap between the implant and cortical bone filled with new mature bone and HA granules. Figure $5 b-$ Without HA clay, showing a small amount of bone ingrowth and seams of fibrous tissue. $\mathrm{H}$, hydroxyapatite; $\mathrm{N}$, newly-developed bone; I, implant (removed); $\mathrm{C}$, cortical bone; $\mathrm{F}$, fibrous tissue. 


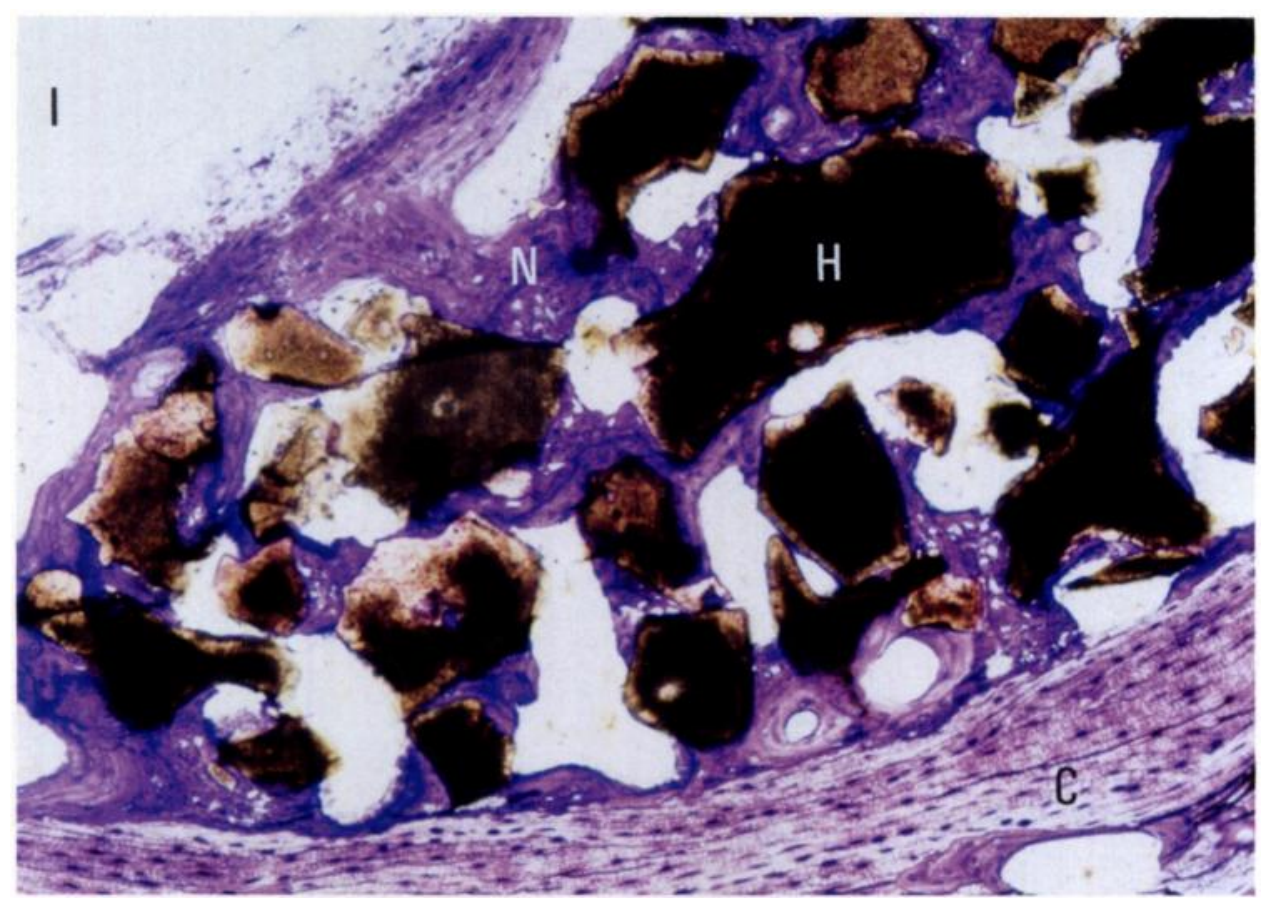

Fig. 6a

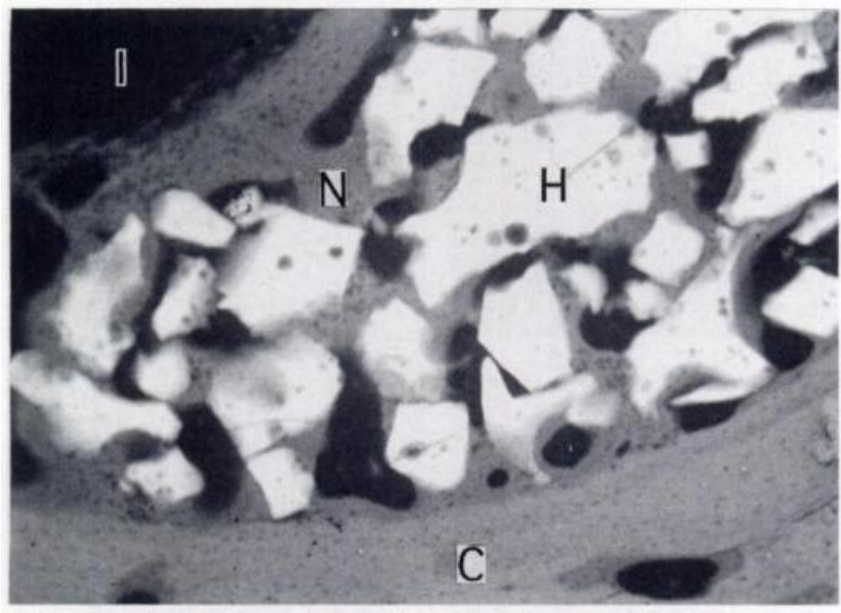

Fig. 6b

Figure 6a - Enlarged view showing HA granules in direct contact and bridged by new bone (toluidine blue $\times 70$ ). Figure $6 \mathrm{~b}-$ Contact microradiograph of the same area showing the new bone as radiodense zones in contact with HA granules. The density of these zones equalled that of cortical bone, showing the calcification of the new bone $(\times 50)$.

contact with HA granules and completely surrounded the implant. No inflammatory or adverse tissue reactions to HA clay were seen; most of the sodium alginate had been absorbed and replaced by the bone (Figs $5 \mathrm{a}$ and $6 \mathrm{a}$ ). Contact microradiographs confirmed that there were many radiodense zones in contact with $\mathrm{HA}$ granules, representing calcified new bone (Fig. 6b).

There was, however, a small amount of bone ingrowth adjacent to the endosteal surface in tibiae without HA clay at 12 weeks, with seams of fibrous tissue as a response to implant micromotion (Fig. 5b). At one week, neither group showed bone ingrowth. The percentage area of the new bone was significantly greater for implants with HA clay at 12 weeks $(\mathrm{p}<0.05 ; 35 \pm 11 \%(24$ to 52$)$ as against $17 \pm$ $14 \%$ (3 to 34 ; Fig. 7 )).

\section{DISCUSSION}

It is evident that the smaller the gap between an uncemented prosthesis and the host bone, the shorter will be the time needed for it to be filled by newly-developed bone. Other methods have been used to fill the gap: autografts, allografts and various ceramics have been studied (Greis et al 1992; Søballe et al 1992; Gie et al 1993; Ling, Kimper- 


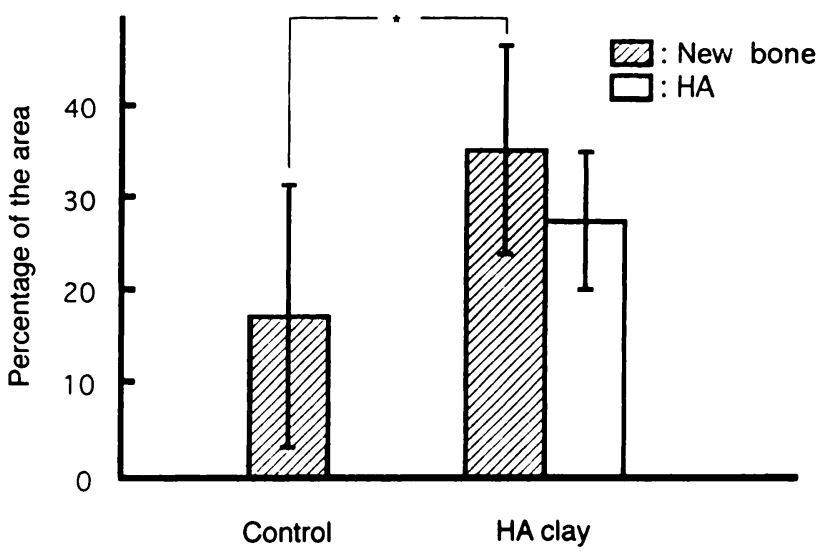

Fig. 7

The percentages of total area occupied by new bone and HA granules a 12 weeks. The area of the new bone was significantly greater for implants with HA clay $(*, p<0.05)$. The error bars show the standard deviation of the mean.

ley and Linder 1993). Most gaps, however, are both fine and irregular, and materials such as HA granules may interfere with the insertion of the implant. Hence the interest in a clay which is easy to handle. Naturally occurring clay has particles of less than $0.005 \mathrm{~mm}$ in size, but it is known that macrophages may stimulate bone resorption when they phagocytose particles of less than $0.05 \mathrm{~mm}$ in size (Murray and Rushton 1990; Salvati, Betts and Doty 1993). HA granules for clinical use need to be $0.1 \mathrm{~mm}$ or more in size to obtain optimal bone ingrowth. Granules of this or greater size, however, will not be turned into a clay by mixing with water: this requires a viscous solution. Sodium alginate was used, since no complications or biotoxicity have been reported after its clinical use for intraoperative local haemostasis (Kakuda, Hoshi and Hayashi 1985) or its ingestion (Anderson et al 1991). In dentistry, alginate with calcium sulphate is regularly used as an impression material (Klein, van der Lubbe and de Groot 1987).

Uncemented prostheses may show excessive movement at the prosthesis-bone interface (Charnley and Kettlewell 1965; Burke et al 1991) and only a small amount of bone ingrowth (Cook et al 1988a,b), and this was obvious in the control group. Localised point contacts cause peak stresses which may exceed the compressive resistance of the bone and cause pressure necrosis. Radiolucencies which may appear at the distal part of a proximally HA-coated femoral stem may result from movement between the stem and the surrounding bone (D'Antonio et al 1992; D’Antonio, Capello and Jaffe 1992). The aim for future prostheses and operative techniques should be early stability to improve anchorage by bone ingrowth.

The study has shown that HA clay is not immediately effective for the initial fixation of the implant, but that in a short time it can provide biological fixation by osseointegration into the implant-bone gap. The significantly greater pull-out strength with HA clay at 12 weeks must depend on this osseointegration since there were no significant differ-

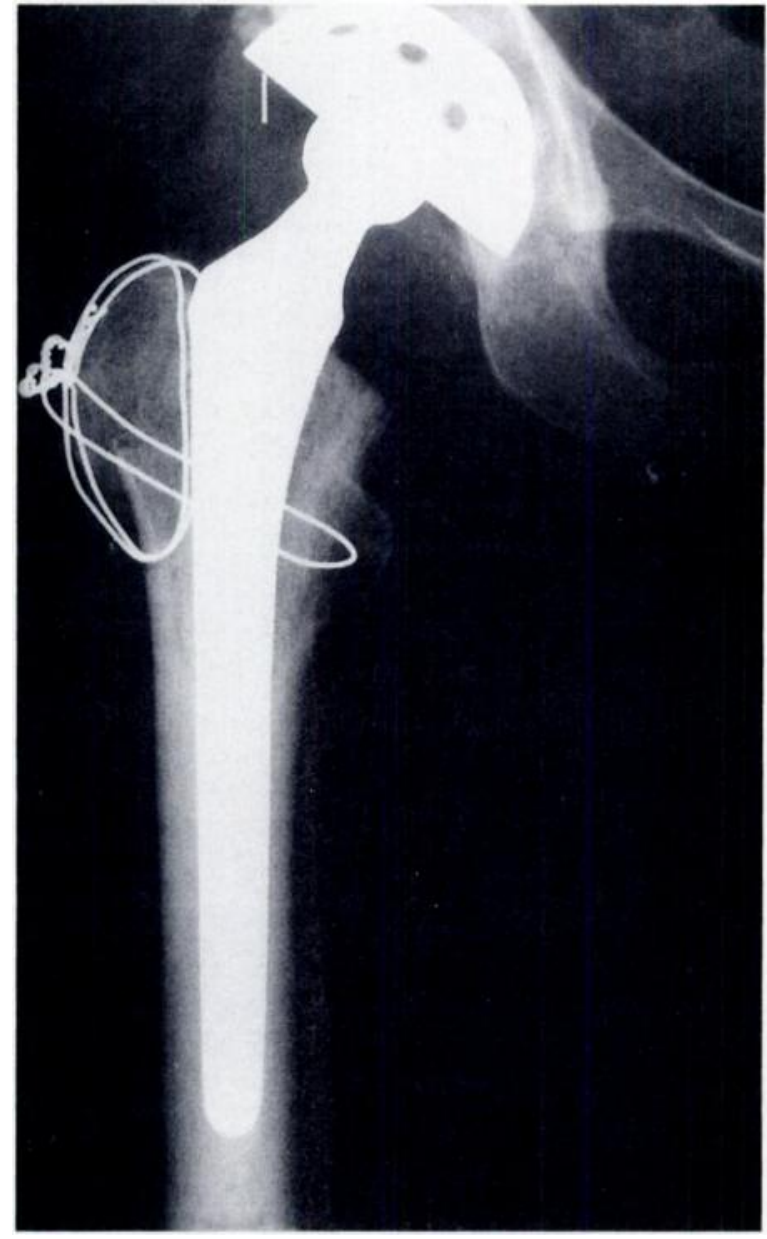

Fig. 8

Radiograph at one month after a primary uncemented total hip arthroplasty using HA clay around the femoral stem. There are no radiolucencies and no evidence of migration of HA granules. Granule sizes ranged from 0.6 to $0.9 \mathrm{~mm}$.

ences in the groups at one week postoperatively. Bone ingrowth, however, must be considerably affected by the quality of host bone and its metabolic status.

Based on the success of the experimental investigation, I have used HA clay in a few clinical cases: one case of femoral head replacement, five cases of primary total hip arthroplasty and two revision arthroplasties. Complete filling of the prosthesis-bone gap with HA clay was obtained in all cases (Fig. 8). No migration of HA granules was seen, which is important, because these could cause extensive abrasion of polyethylene or cartilage if they entered a joint space. I therefore recommend caution until more clinical data become available, and insist on a postoperative period of absent or partial weight-bearing to allow optimal bony bonding of the HA granules.

The author wishes to thank Professor Kazuo Terayama. Department of Orthopaedic Surgery, Shinshu University School of Medicine, Dr Tsunenori Takei, Department of Orthopaedic Surgery, Nagano Rehabilitation Centre, Professor William Naldo Capello. Department of Orthopaedic Surgery, Indiana University Medical Centre, and Dr Eiji Kitagawa, Department of Orthopaedic Surgery, National Toshin Hospital for their advice. He acknowledges the excellent technical assistance of Professor Michio Ito and Dr Toshio Yamagishi, Institute for Dental Science. Matsu- 
moto Dental College. He also thanks Sumitomo Cement Co Ltd and Kyosei Pharmaceutical Co Ltd for supplying materials.

No benefits in any form have been received or will be received from a commercial party related directly or indirectly to the subject of this article.

\section{REFERENCES}

Anderson DMW, Brydon WG, Eastwood MA, Sedgwick DM. Dietary effects of sodium alginate in humans. Food Additives and Contaminants 1991:8:237-48.

Bauer TW, Geesink RCT, Zimmerman R, McMahon JT. Hydroxyapatite-coated femoral stems: histological analysis of components retrieved at autopsy. J Bone Joint Surg [Am/ 1991:73-A:1439-52.

Bobyn JD, Engh CA, Glassman AH. Histologic analysis of a retrieved microporous-coated femoral prosthesis: a seven-year case report. Clin Orthop 1987:224:303-10.

Burke DW, O’Connor DO, Zalenski EB, Jasty M, Harris WH. Micromotion of cemented and uncemented femoral components. $J$ Bone Joint Surg |Br/ 1991:73-B:33-7.

Cameron HU. Six-year results with a microporous-coated metal hip prosthesis. Clin Orthop 1986:208:81-3.

Carlsson L, Röstlund T, Albrektsson B, Albrektsson T. Implant fixation improved by close fit: cylindrical implant-bone interface studied in rabbits. Acta Orthop Scand 1988:59:272-5.

Charnley J, Kettlewell J. The elimination of slip between prosthesis and femur. J Bone Joint Surg [Br] 1965:47-B:56-60.

Collier JP, Mayor MB, Chae JC, et al. Macroscopic and microscopic evidence of prosthetic fixation with porous-coated materials. Clin Orthop 1988:235:173-80.

Collier JP, Surprenant VA, Mayor MB, et al. Loss of hydroxyapatite coating on retrieved. total hip components. J Arthroplasty 1993:8:389-93

Cook SD, Barrack RL. Thomas KA, Haddad RJ Jr. Quantitative analysis of tissue growth into human porous total hip components. $J$ Arthroplasty 1988a:3:249-62.

Cook SD, Thomas KA, Haddad RJ Jr. Histologic analysis of retrieved human porous-coated total joint components. Clin Orthop 1988b:234:90-101.

D'Antonio JA, Capello WN, Crothers OD, Jaffe WL, Manley MT. Early clinical experience with hydroxyapatite-coated femoral implants. J Bone Joint Surg [Am] 1992:74-A:995-1008.

D’Antonio JA, Capello WN, Jaffe WL. Hydroxylapatite-coated hip implants: multicenter three-year clinical and roentgenographic results. Clin Orthop 1992:285:102-15.

Engh GA, Bobyn JD, Petersen TL. Radiographic and histologic study of porous coated tibial component fixation in cementless total knee arthroplasty. Orthopedics 1988:11:725-31

Furlong RJ, Osborn JF. Fixation of hip prostheses by hydroxyapatite ceramic coatings. J Bone Joint Surg [Br] 1991:73-B:741-5.

Geesink RGT, de Groot K, Klein CPAT. Bonding of bone to apatitecoated implants. J Bone Joint Surg /Br/ 1988:70-B:17-22.

Geist CE, Stracher MA, Grove AS Jr. Orbital augmentation by hydroxylapatite-based composites: a rabbit study and comparative analysis. Ophthal Plast Reconstr Surg 1991:7:8-22.

Gie GA, Linder L, Ling RSM, et al. Impacted cancellous allografts and cement for revision total hip arthroplasty. J Bone Joint Surg $[\mathrm{Br}]$ 1993;75-B:14-21.

Goldring SR, Schiller AL, Roelke M, et al. The synovial-like membrane at the bone-cement interface in loose total hip replacements and its proposed role in bone lysis. J Bone Joint Surg [Am] 1983:65-A:575 84.
Greis PE, Kang JD, Silvaggio V, Rubash HE. A long-term study on defect filling and bone ingrowth using a canine fiber metal total hip model. Clin Orthop 1992:274:47-59.

Jarcho M. Calcium phosphate ceramics as hard tissue prosthetics. Clin Orthop 1981:157:259-78.

Kakuda C, Hoshi K, Hayashi K. Clinical study of sodium alginate "ALTO" in the field of obstetrics and gynaecology (in Japanese). Jpn Pharmacol Ther 1985:13:367-70.

Kamegaya M, Shinohara Y, Shinada Y, et al. The use of a hydroxyapatite block for innominate osteotomy. J Bone Joint Surg $|B r|$ 1994;76-B:123-6.

Klein CPAT, van der Lubbe HBM, de Groot $\mathrm{K}$. A plastic composite of alginate with calcium phosphate granulate as implant material: an in vivo study. Biomaterials 1987:8:308-10.

Ling RSM, Kimperley AG, Linder L. Histology of cancellous impaction in the femur. J Bone Joint Surg [Br] 1993:75-B:69.3-6.

Maruyama M, Terayama K, Ito M, Takei T, Kitigawa E. Hydroxyapatite clay for gap filling and adequate bone ingrowth. $J$ Biomed Mater Res 1995:29:In press

Mjöberg B, Pettersson H, Rosenqvist R, Rydholm A. Bone cement. thermal injury and the radiolucent zone. Acta Orthop Scand 1984;55:597-600.

Murray DW, Rushton N. Macrophages stimulate hone resorption when they phagocytose particles. J Bone Joint Surg [Br/ 1990:72-B:98892.

Neumann L, Freund KG, Sørenson KH. Long-term results of Charnley total hip replacement: review of 92 patients at 15 to 20 years. J Bone Joint Surg $[B r \mid$ 1994:76-B:245-51.

Salvati EA, Betts F, Doty SB. Particulate metallic debris in cemented total hip arthroplasty. Clin Orthop 1993:293:160-73.

Schulte KR, Callaghan JJ, Kelley SS, Johnston RC. The outcome of Charnley total hip arthroplasty with cement after a minimum twentyyear follow-up: the results of one surgeon. J Bome Joint Surg [Am] 1993;75-A:961-75.

Shen W-J, Chung K-C, Wang G-J, McLaughlin RE. Mechanical failure of hydroxyapatite- and polysulfone-coated titanium rods in a weightbearing canine model. J Arthroplasty 1992:7:43-9.

Søballe K, Hansen ES, Brockstedt-Rasmussen H, et al. Gap healing enhanced by hydroxyapatite coating in dogs. Clin Orthop 1991: 272:300-7.

Søballe K, Hansen ES, Brockstedt-Rasmussen H, Pedersen CM, Bünger C. Bone graft incorporation around titanium-alloy- and hydroxyapatite-coated implants in dogs. Clin Orthop 1992:274 282-93.

Søballe K, Hansen ES, Brockstedt-Rasmussen H, Bünger C. Hydroxyapatite coating converts fibrous tissue to bone around loaded implants. J Bone Joint Surg [Br] 1993:75-B:270-8.

Thomas KA, Kay JF, Cook SD, Jarcho M. The effect of surface macrotexture and hydroxylapatite coating on the mechanical strengths and histologic profiles of titanium implant materials. J Biomed Mater Res 1987:21:1395-414.

Tisdel CL, Goldberg VM, Parr JA, et al. The influence of a hydroxyapatite and tricalcium-phosphate coating on bone growth into titanium fiber-metal implants. J Bone Joint Surg (Am/ 1994:76-A:159-71.

Uchida A, Araki N, Shinto Y, et al. The use of calcium hydroxyapatite ceramic in bone tumour surgery. J Bone Joint Surg $\mid \mathrm{Br}$ 1990:72-B:298-302.

Wroblewski BM, Siney PD. Charnley low-friction arthroplasty of the hip long-term results. Clin Orthop 1993:292:191-201. 